\title{
Berhane Hewan ('Light for Eve'): A program to support married and unmarried adolescent girls in rural Amhara Region, Ethiopia
}

Population Council

Follow this and additional works at: https://knowledgecommons.popcouncil.org/departments_sbsr-pgy

Part of the Demography, Population, and Ecology Commons, Family, Life Course, and Society Commons, Gender and Sexuality Commons, and the International Public Health Commons How does access to this work benefit you? Let us know!

\section{Recommended Citation}

"Berhane Hewan ('Light for Eve'): A program to support married and unmarried adolescent girls in rural Amhara Region, Ethiopia," program brief. Addis Ababa: Population Council, 2006. 


\title{
Berhane Hewan
}

\author{
('LIGHT FOR EVE')
}

\section{A program to support married and unmarried adolescent girls in rural Amhara Region, Ethiopia}

In the Amhara region of Ethiopia, rates of child marriage are among the highest in the world. Half of all girls in Amhara are married before their 15th birthday. ${ }^{1}$ In 2004, the Ministry of Youth and Sports, in conjunction with the Population Council, conducted a survey of more than 1,800 adolescent boys and girls in two woredas (districts) in rural Amhara region. Among the considerable number of girls who were married, most felt their marriage was too early, did not know their husbands beforehand, and had sexual initiation as a result of force. Ninety-five percent of the girls surveyed did not know their husband before marriage, and 85 percent were given no forewarning that they were going to be married. More than two-thirds of married girls reported that they had not started menstruating when they had sex for the first time. Many of these marital unions are unstable, and 12 percent of girls in Amhara aged 10-19 are already divorced. Many girls fled their homes for urban areas to escape early marriage. A parallel survey conducted in slum areas of Addis Ababa found a considerable number of female migrants came to the city to escape early marriage, most of whom ended up as child domestic workers or sex workers.

Berhane Hewan (meaning "Light for Eve" in Amharic) is a program underway in rural Amhara region designed to assist unmarried girls by imparting the knowledge, skills, and resources they need to avoid child marriage as well as give support to adolescent girls who are already married. With support from UNFPA, DFID, and Turner Foundation the program is implemented by the Ministry of Youth and Sport and the Regional Youth Bureaus, with technical assistance from the Population Council. The program promotes functional literacy, life skills, livelihoods skills, and reproductive health education. In developing the project, Regional Youth Bureau staff felt that sensitization on the dangers of early marriage was insufficient and that the program needed to address the livelihoods needs of the communities and economic motives for the practice of child marriage. Accordingly, incentives such as community wells were added to encourage families to allow their daughters to participate in girls' groups.

\section{Programmatic options for girls in different circumstances}

Girls who enroll in the program have three options: they may join formal schooling, take part in girls clubs including non-formal education and life skills led by adult female mentors, or participate in weekly married girls clubs. Separate groups of married girls and unmarried girls are formed by adult female mentors, many of whom are former teachers or respected women from the community. Unmarried girls groups meet five times per week and married girls groups meet once per week. Community involvement is also a major component of the project. To create an enabling and supportive environment, monthly community conversations are undertaken to discuss child marriage and issues that affect the well-being of girls.
"I hate early marriage. I was married at an early age and my in-laws forced me to sleep with my husband and he made me suffer all night. After that, whenever day becomes night, I get worried thinking that it will be like that. This is what I hate most." -Amhara girl, age 11 , married at age 5 , first sex at age 9

${ }^{1}$ Estimates based on young women aged 20 to 24 in Ethiopia Demographic and Health Survey, 2000. 
"This [early marriage] is inherited culture and people do it because they want to do what others do. They

want to pay back other families who invited them to weddings before." (Girl, age 18 , married at age 10, attending married girls' club)

[When they were trying to marry me] I escaped to my grandparents. But they took me back to my parents

and decided to marry me when I was 8 years old. My husband was 12 year old and

I started to live with him. After 5 years, he left me and I returned back to my family.

I am now a member of Berhane Hewan and I would like to tell you that getting married at an early age is unsafe. (Girl, age 18, married at age 8 , divorced, attending married girls' club)

\section{Engaging large numbers of girls in the program}

The project has already received an enthusiastic response from the community-over 700 girls joined Berhane Hewan in the first two months, amounting to roughly 40 percent of eligible girls. Seventy-seven percent of participants are never married girls, 20 percent are married girls, and roughly 3 percent are divorced. While most youth programs reach older adolescents, over half of Berhane Hewan's participants are younger adolescents aged 10 to 14, a traditionally hard group to reach. Over half of the participants are being supported to return to or remain in formal schooling, including 17 married girls. Over 130 girls are participating in married girls clubs.

Distribution of girls in Berhane Hewan clubs, by age group and marital status*

\begin{tabular}{l|c|c|c|c|c|c}
\hline & \multicolumn{3}{|c|}{ Age group } & \multicolumn{3}{c}{ Marital Status } \\
\cline { 2 - 7 } & Total Participants & 10 to 14 & 15 to 19 & Never married & Married & Divorced \\
\hline Married girls club & 137 & 1 & 134 & 0 & 120 & 17 \\
Unmarried girls club & 103 & 56 & 48 & 101 & 0 & 2 \\
Formal Schooling & 457 & 354 & 99 & 440 & 17 & 0 \\
Total & 697 & 411 & 281 & 541 & 137 & 19 \\
\hline
\end{tabular}

Rows may not sum due to missing values for some variables

After six months, fully 98 percent of enrollees were still in the program with only 13 girls having dropped out. Seven of the 13 drop outs were married girls. The project has provided parents an alternative to early marriage. Among parents of unmarried girls, 88 percent said that if Berhane Hewan had not been available to them, they would have married off their daughters.

\section{Evaluating the impact of Berhane Hewan on girls and communities}

The impact of Berhane Hewan is being assessed using baseline and endline surveys in project and control sites. A baseline survey was conducted in 2004 in the project area and a selected control area, which was comparable to the project site, but at a sufficient distance to minimize contamination. In 2006, an endline survey will be conducted in the same areas. Comparison of surveys will allow researchers to assess population-level changes resulting from the project, using the comparison area to control for changes that took place independent of the intervention.

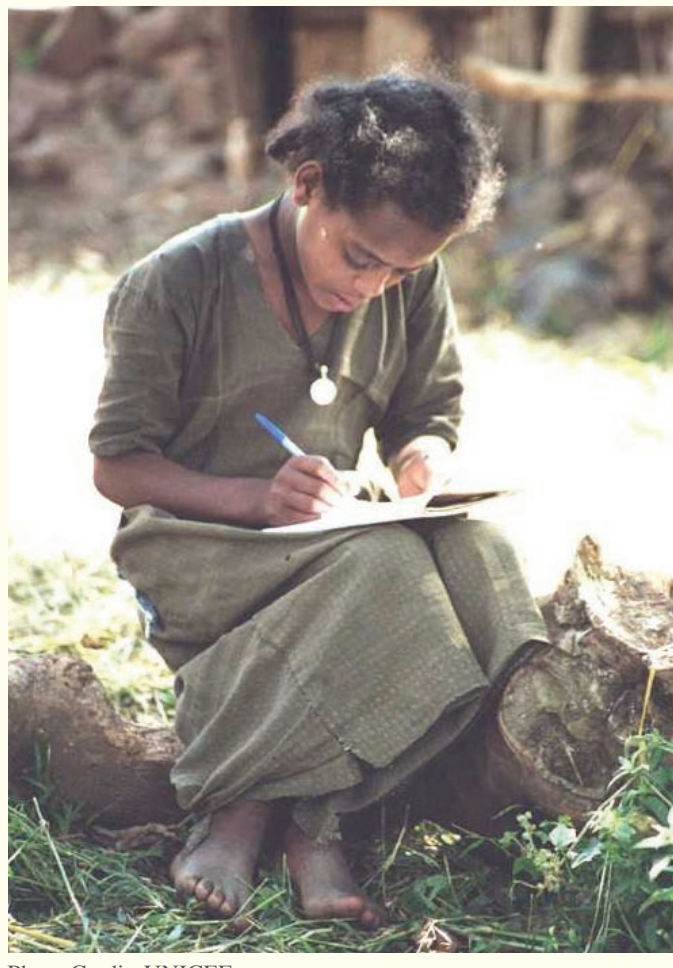

Photo Credit: UNICEF

\section{Resources}

Erulkar AS, Mekbib T, Simie N, Gulema T. 2004. "The experience of adolescence in rural Amhara region Ethiopia" Accra: Population Council.

Erulkar AS, Mekbib T, Simie N, Gulema T. 2004. "Adolescent life in low-income and slum areas of Addis Ababa Ethiopia" Accra: Population Council.

Erulkar AS, Mekbib T, Simie N, Gulema T. 2006. "Migration and Vulnerability Among Adolescents in Slum Areas of Addis Ababa, Ethiopia," Journal of Youth Studies, Vol. 9 , No. 3 , July, 261-274

Child Marriage Briefing Sheet: Ethiopia, Population Council, NY, www.popcouncil.org

Partners: UNFPA, UNICEF, UNF, DFID and Turner Foundation

For more information on Berhane Hewan program, contact:

Dr. Tekle Ab Mekbib

Population Council

P.O. Box 33998

Addis Ababa, Ethiopia

mekbibt@ethionet.et
W/o Tsahai Gulema

Ministry of Youth \& Sports

P.O. Box 3241

Addis Ababa, Ethiopia
Regional Youth \& Sports Bureau P.O. Box 25

Bahir Dar, Ethiopia
Dr. Annabel Erulka Population Council P.O. Box CT 4906 Accra, Ghana aerulkar@pcaccra.org
Helen Amdemikael UNFPA Ethiopia P.O. Box 5580 Addis Ababa, Ethiopia amdemikael@unfpa.org 